\title{
Field Evaluation of Plant Defense Inducers for the Control of Citrus Huanglongbing
}

\author{
Jinyun Li, Pankaj Trivedi, and Nian Wang
}

Citrus Research and Education Center, Department of Microbiology and Cell Science, Institute of Food and Agricultural Sciences (IFAS), University of Florida, Lake Alfred 33850.

Accepted for publication 15 September 2015 .

\begin{abstract}
Li, J., Trivedi, P., and Wang, N. 2016. Field evaluation of plant defense inducers for the control of citrus huanglongbing. Phytopathology 106:37-46.

Huanglongbing (HLB) is currently the most economically devastating disease of citrus worldwide and no established cure is available. Defense inducing compounds are able to induce plant resistance effective against various pathogens. In this study the effects of various chemical inducers on HLB diseased citrus were evaluated in four groves (three with sweet orange and one with mandarin) in Florida (United States) for two to four consecutive growing seasons. Results have demonstrated that plant defense inducers including $\beta$-aminobutyric acid (BABA), 2,1,3-benzothiadiazole (BTH), and 2,6-dichloroisonicotinic acid (INA), individually or in combina-

also exhibited positive control effects on HLB. After three or four applications for each season, the treatments AA (60 to $600 \mu \mathrm{M})$, BABA $(0.2$ to $1.0 \mathrm{mM})$, BTH $(1.0 \mathrm{mM})$, INA $(0.1 \mathrm{mM}), 2$-DDG $(100 \mu \mathrm{M})$, BABA $(1.0 \mathrm{mM})$ plus BTH $(1.0 \mathrm{mM})$, BTH $(1.0 \mathrm{mM})$ plus AA $(600 \mu \mathrm{M})$, and BTH $(1.0 \mathrm{mM})$ plus 2-DDG $(100 \mu \mathrm{M})$ slowed down the population growth in planta of 'Candidatus Liberibacter asiaticus', the putative pathogen of HLB and reduced HLB disease severity by approximately 15 to $30 \%$ compared with the nontreated control, depending on the age and initial HLB severity of infected trees. These treatments also conferred positive effect on fruit yield and quality. Altogether, these findings indicate that plant defense inducers may be a useful strategy for the management of citrus HLB.
\end{abstract} tion, were effective in suppressing progress of HLB disease. Ascorbic acid (AA) and the nonmetabolizable glucose analog 2-deoxy-D-glucose (2-DDG)
Additional keywords: induced resistance, salicylic acid.
Citrus huanglongbing (HLB), also known as citrus greening, is currently the most destructive disease of citrus and has been rapidly spreading worldwide, resulting in dramatic economic losses. HLB has been known in East Asia for over a century and is currently widespread in most citrus areas of Asia, Africa, and the Americas. HLB has been established in Brazil in 2004 (Gottwald et al. 2007). In the United States, since first identified in Florida in 2005 (Sutton et al. 2005), HLB has expanded to Louisiana, South Carolina, Georgia, Texas, and California (Wang and Trivedi 2013). It has also been discovered in Cuba, Belize, Jamaica, Mexico, and other countries in the Caribbean (Wang and Trivedi 2013). All commercial citrus varieties currently available are susceptible to HLB and the citrus industries in affected areas have suffered a decline in both production and profit (Bové 2006; Gottwald et al. 2007; Wang and Trivedi 2013). In Florida, HLB is now present in all commercial citrus-producing counties and is destroying the $\$ 9$ billion citrus industry. It was estimated that HLB has played a key role in the loss of about 100,000 citrus acres since 2007 in Florida and has cost Florida's economy approximately $\$ 3.6$ billion in lost revenues since 2006 (Gottwald 2010; Wang and Trivedi 2013).

Citrus HLB is associated with a phloem-limited fastidious $\alpha$-proteobacterium belonging to the 'Candidatus' genus Liberibacter (Jagoueix et al. 1994). Currently, three species of ' $\mathrm{Ca}$. Liberibacter' have been identified to cause HLB disease: ' $C a$. L. asiaticus' (Las), ' $C a$. L. africanus', and ' $\mathrm{Ca}$. L. americanus' (Gottwald 2010). These bacteria have not been cultivated in pure culture. HLB pathogen is mainly spread by the insect vector psyllid in the field (Bové 2006; Pelz-Stelinski et al. 2010).

Corresponding author: N. Wang; E-mail address: nianwang@ufl.edu

*The $\boldsymbol{e}$-Xtra logo stands for "electronic extra" and indicates that four supplementary figures are published online.

http://dx.doi.org/10.1094/PHYTO-08-15-0196-R

(C) 2016 The American Phytopathological Society
There are two psyllid species transmitting Liberibacters: Asian citrus psyllid (Diaphorina citri) in Asia and the Americas (Bové 2006; Halbert 2005; Teixeira et al. 2005) and African citrus psyllid (Trioza erytreae) in Africa (Bové 2006). Las and Asian citrus psyllid are the most prevalent and important throughout HLB-affected citrus-growing areas worldwide (Bové 2006). Las propagates in the phloem of the host plants, resulting in die-back, small leaves, yellow shoots, blotchy mottles on leaves, corky veins, malformed and discolored fruit, aborted seed, premature fruit drop, root loss, and eventually tree death (Bové 2006; Gottwald et al. 2007; Wang and Trivedi 2013). The life span for the profitable productivity of infected citrus trees is dramatically shortened as the disease severity increases and the yield is significantly reduced (Gottwald et al. 2007). The understanding of virulence mechanism of the bacterial pathogen is limited, due to the difficulty in culturing Las. So far, most molecular insights of the HLB biology and Las pathogenicity are derived from the genome sequences of Las and other related Liberibacters (Duan et al. 2009; Lin et al. 2011; Leonard et al. 2012; Wulff et al. 2014).

An integrated control program has been recommend for HLB in commercial orchards by the United Nations Development Program, Food and Agriculture Organization (UNDP, FAO) Southeastern Asian citrus rehabilitation project (Aubert 1990). The program highlights controlling psyllid vectors with insecticides, reducing inoculum through removal of HLB-symptomatic trees, propagating and using pathogenfree budwood and nursery trees. In Florida, foliar nutrition programs coupled with vector control are often used to slow down the spread of HLB and reduce devastating effects of the disease (Gottwald 2010). These control practices have showed limited effect for preventing further spread of HLB. Recently, various treatment strategies including applications of penicillin and streptomycin (Zhang et al. 2011), enhanced nutrient program (Gottwald et al. 2012), thermotherapy (Hoffman et al. 2013), soil-conditioners (Xu et al. 2013), and small molecules targeting Las virulence traits including osmotic stress tolerance (Pagliai et al. 2014), have been examined for HLB disease management and some 
showed promising progress. However, no effective approach has been established to control HLB and stop it from spreading to new citrusproduction areas.

Induced resistance either locally or systemically may confer longlasting protection against a broad spectrum of plant diseases (Durrant and Dong 2004; Walters et al. 2013). The plant defense mechanisms can be activated by pathogens (Durrant and Dong 2004), beneficial microorganisms (Weller et al. 2012; Zamioudis and Pieterse 2012), or by chemical inducers (Walters et al. 2013). Tremendous effort has been put into the development of agents which can mimic natural inducers of resistance. These include acibenzolar-S-methyl (ASM), benzothiadiazole (BTH), 2,6-dichloroisonicotinic acid (INA), $\beta$-aminobutyric acid (BABA), oligosaccharide from plant and fungal cell walls, and probenazole. These agents could induce plant resistance effective against a wide range of pathogens including bacteria, fungi, viruses, nematodes, and parasitic weeds (Beckers and Conrath 2007), even though effects varied with concentrations and pathosystems (Vallad and Goodman 2004; Walters et al. 2005). For example, soil applications of systemic acquired resistance (SAR) elicitors induced systemic resistance against canker under greenhouse conditions and showed season-long control of canker epidemics on young citrus trees (Francis et al. 2009). In addition, BABA induced citrus resistance against psyllids in greenhouse (Tiwari et al. 2013), suggesting the potential of BABA for management of HLB. In certain nutrient/SAR programs, salicylic acid (SA) and/or its analogs were applied as foliar amendments to act against the HLB pathogen by activating the SAR pathway and the effects on disease expression of HLB-infected trees and on fruit yield remain to be demonstrated (Stansly et al. 2014). Overall, no conclusive study has been conducted regarding how to control HLB by inducing plant defense.

The purpose of this study was to evaluate the effects of various chemical inducer treatments on HLB progression and fruit production under field conditions in order to determine the feasibility of plant defense inducers as a strategy for the control and management of citrus HLB. Two years after treatments were initiated, the induced defense reactions have exhibited positive influence in slowing down HLB disease progress and sustaining fruit productivity, which validated the potential of pursuing chemical plant defense inducers for management of citrus HLB.

\section{MATERIALS AND METHODS}

Field plot design. Experiments $I$ and II. The trials were conducted in a block of 7-year-old (at the beginning of the study) Midsweet orange (Citrus sinensis (L.) Osbeck) on Carrizo citrange (Poncirus trifoliata [L.] Raf. $\times$ C. sinensis [L] Osbeck.) rootstock planted in Mid-Florida Foundation grove, Florida in 2004. The experimental design was a completely randomized design with 11 treatments, each consisting of five trees for experiment I; and 18 treatments, each consisting of nine trees for experiment II. Treatment applications were made every 3 or 4 months when flush was present starting with the spring flush in April 2011 for experiment I and March 2012 for experiment II. Individual trees were chosen for the experiment based upon the presence of the symptoms of HLB. An attempt was made to select trees in the same stage of HLB symptom expression; i.e., initial symptoms observed in less than $30 \%$ of the canopy. All trees selected for the experiment were confirmed to be HLB-positive via a real-time quantitative polymerase chain reaction (qPCR) assay (Trivedi et al. 2009). All trees within the trial area were maintained at commercial standards (conventional citrus insecticide, fertilizer, and herbicide applications were applied to the entire plantation).

Experiment III. The trial was performed in a block of 10 -year-old (at the beginning of the study) Murcott mandarin (Citrus reticulata (L.) Blanco) on Cleopatra mandarin (Citrus reticulata (L.) Blanco) rootstock planted in Lake Wales, Florida in 2003. The experimental design was a completely randomized design with 11 treatments, each consisting of 10 trees as replicates. Treatment applications were made every 3 or 4 months when flush was present starting with the spring flush in March 2013. Individual trees were chosen for the experiment based upon the presence of the symptoms of HLB. An attempt was made to select trees in the same stage of HLB symptom expression; i.e., initial symptoms observed in less than $30 \%$ of the canopy. All trees selected for the experiment were confirmed to be HLB-positive via qPCR assays (Trivedi et al. 2009). All trees within the trial area were maintained at commercial standards.

Experiment IV. The trial was conducted in a block of 4-year-old (at the beginning of the study) Valencia sweet orange (Citrus sinensis (L.) Osbeck Blanco) on Swingle citrumelo (Citrus paradisi Macf. 'Duncan' grapefruit $\times$ Poncirus trifoliata (L.) Raf.) rootstock planted in Lake Wales, Florida in 2009. The experimental design was a completely randomized design with 11 treatments, each consisting of 10 trees as replicates. Treatment applications were made every 3 or 4 months when flush was present starting with the spring flush in March 2013. Individual trees were chosen for the experiment based upon the presence of the symptoms of HLB. An attempt was made to select trees in the same stage of HLB symptom expression; i.e., initial symptoms observed in less than $20 \%$ of the canopy. All trees selected for the experiment were confirmed to be HLBpositive with qPCR assays (Trivedi et al. 2009). All trees within the trial area were maintained at commercial standards.

Plant defense inducer treatments. Individual treatments were applied with a back pack sprayer until runoff to ensure complete coverage as follows:

Experiment I: (1) BABA (15 $\mu \mathrm{M})$; (2) BABA (150 $\mu \mathrm{M})$; (3) 2, 6-dichloroisonicotinic acid (INA) $(0.1 \mathrm{mM})$; (4) INA (0.5 mM); (5) ascorbic acid (AA) $(60 \mu \mathrm{M})$; (6) AA $(600 \mu \mathrm{M})$; (7) copper sulfate $(\mathrm{CuSO} 4)(0.3 \mathrm{mM})$; (8) BABA $(150 \mu \mathrm{M})$ and INA (0.5 mM); (9) INA $(0.5 \mathrm{mM})$ and AA $(600 \mu \mathrm{M})$; (10) INA $(0.5 \mathrm{mM})$ and $\mathrm{CuSO} 4(0.3 \mathrm{mM})$; and (11) water as control.

Experiment II: (1) BABA (0.2 mM); (2) BABA (1.0 mM); (3) INA (0.1 mM); (4) INA (0.5 mM); (5) 2,1,3-benzothiadiazole (BTH) $(0.1 \mathrm{mM})$; (6) BTH (1.0 mM); (7) AA $(60 \mu \mathrm{M})$; (8) AA $(600 \mu \mathrm{M})$; (9) 2-deoxy-D-glucose (2-DDG) $(10 \mu \mathrm{M})$; (10) 2-DDG $(100 \mu \mathrm{M})$; (11) BABA (1.0 mM) and INA (0.5 mM); (12) BABA (1.0 mM) and BTH (1.0 mM); (13) BABA $(1.0 \mathrm{mM})$ and AA $(600 \mu \mathrm{M})$; (14) INA $(0.5 \mathrm{mM})$ and AA $(600 \mu \mathrm{M})$; (15) INA $(0.5 \mathrm{mM})$ and 2-DDG $(100 \mu \mathrm{M})$; (16) BTH $(1.0 \mathrm{mM})$ and AA $(600 \mu \mathrm{M}) ;(17)$ BTH $(1.0 \mathrm{mM})$ and 2-DDG $(100 \mu \mathrm{M})$; and (18) water as control.

Experiments III and IV: (1) water as control; (2) AA $(60 \mu \mathrm{M})$; (3) AA $(600 \mu \mathrm{M})$; (4) BABA $(0.2 \mathrm{mM})$; (5) BABA (1.0 mM); (6) INA (0.1 mM); (7) INA (0.5 mM); (8) BTH (0.1 mM); (9) BTH (1.0 mM); (10) 2-DDG) $(25 \mu \mathrm{M})$; and (11) 2-DDG (100 $\mu \mathrm{M})$.

All the chemicals were purchased from Sigma (St. Louis, MO) or Fisher Scientific (Pittsburgh, PA).

HLB disease assessment. Disease severity data were recorded during 13 visual assessments from April 2011 through September 2014 for experiment I, 10 assessments from March 2012 through September 2014 for experiment II, and five assessments from March 2013 through February 2015 for experiments III and IV. In experiment I, the evaluations were performed at $0,5,8,11,14,17$, $20,23,27,32,35$, and 38 months after initial application (MAI); in experiment II, evaluations were performed at $0,3,6,9,12,15,19$, 24, 27, and $30 \mathrm{MAI}$; and in experiments III and IV, evaluations were performed at $0,6,12,18$, and 23 MAI. To estimate disease severity, the method described by Gottwald et al. (2007) was applied. Briefly, each tree was divided into eight sections, i.e., an upper and lower hemisphere and each hemisphere was subdivided into four equal sections. Then, each section was scored individually on a 0 to 5 scale that indicates the proportion of limbs expressing HLB symptoms within each section $(0=$ no limbs; $1=1$ to $20 \%$ limbs; $2=20$ to $40 \%$ limbs; $3=40$ to $60 \%$ limbs; $4=60$ to $80 \%$ limbs; and $5=80$ to $100 \%$ limbs). This resulted in an overall severity rating of 0 to 40 for each 
tree. For each experiment the disease severity data from individual evaluations were also combined into a single value that combined disease progress from the initial application (MAI of 0) until the most recent evaluation. This value, expressed as the area under the disease progress stairs (AUDPS), and its standardized (sAUDPS) form, was calculated according to the method by Simko and Piepho (2012). The AUDPS approach improves the estimation of disease progress compared with the area under the disease progress curve (AUDPC) as it gives a weight closer to optimal to the first and last observations.

Quantitative real-time PCR (qPCR) to estimate Las titer in leaf samples. To estimate the Las bacterial titer in treated trees, eight leaves with mottling symptoms were collected from each tree and, a combined sample of $100 \mathrm{mg}$ of midrib was excised for DNA extraction. DNA from leaf samples was extracted using the Wizard Genomic DNA purification kit (Promega Corp., Madison, WI) following the protocol for isolating genomic DNA from the plant tissue. The extracted DNA was quantified using a nano-drop spectrophotometer (NanoDrop Technologies, Wilmington, DE) and adjusted to $100 \mathrm{ng} / \mu \mathrm{l}$.

qPCR assays were performed in a 96-well plate using an ABI 7500 fast real-time PCR system (Applied Biosystems, Foster City, CA). The primer/probe set CQULA04F-CQULAP10P-CQULA04R targeting the $\beta$-operon region of Las was used (Wang et al. 2006) and qPCR were performed according to the conditions described by Trivedi et al. (2009). Each individual sample was replicated three times and the whole reaction was repeated twice. Raw data were analyzed using ABI SDS software with the default settings of the software except that the threshold was adjusted to 0.02 following the instruction of the QuantiTect Probe PCR Kits (Qiagen). The standard equation $Y=11.607-0.288 X$, where $Y$ is the estimated log concentration of templates and $X$ is the qPCR Ct values, as described by Trivedi et al. (2009), was used to convert individual $\mathrm{Ct}$ values into bacterial population as genome equivalents or cells $(1$ cell $=1$ genome equivalent) per gram of samples.

Real-time reverse transcription PCR analysis of plant gene expression. Leaves from treated trees were collected to monitor the induction of plant defense reaction. Three biological repetitions per treatment were used per time period and each sample consisted of combined four leaves from one plant (a total of three plants were assayed per treatment). Samples were collected at 0 (pretreatment), 1, 2, 3, and 6 days for experiment I and at 0 (pretreatment), 1, 2, 4, and 6 days for experiment II after a single application of treatments and immediately frozen in liquid nitrogen and stored at $-80^{\circ} \mathrm{C}$ until processed.

Total RNA was extracted by grinding two leaves per sample in liquid nitrogen and $200 \mathrm{mg}$ of tissue was processed using the RNeasy Mini kit for plant tissue (Qiagen), and contaminated genomic DNA was removed using a TURBO DNA-free kit (Ambion, Austin, TX), following the manufacturer's instructions. RNA purity and quality were assessed with a NanoDrop ND-1000 spectrophotometer (NanoDrop Technologies, Wilmington, DE). RNA concentration was adjusted to $50 \mathrm{ng} / \mu \mathrm{l}$ and $2 \mu \mathrm{l}$ of sample was used for quantitative reverse transcription-PCR (qRT-PCR) relative quantitation of gene expression.

A one-step qRT-PCR was performed with a 7500 fast real-time PCR system (Applied Biosystems) using a QuantiTect SYBR green RT-PCR kit (Qiagen) following the manufacturer's instructions. The gene specific primers used were previously designed (Fan et al. 2012; Francis et al. 2009) (Table 1). Those primers targeted the $\beta$-1,3-glucanase $(P R-2)$, callose synthase 1 (calS1), and phloemspecific lectin PP2-like protein ( $p p 2$ ) genes from Citrus sinensis. The house keeping gene encoding glyceraldehyde-3-phosphate dehydrogenase-C (GAPDH-C) was used as the endogenous control. The relative fold change in target gene expression was calculated using the formula $2^{-\Delta \Delta C T}$ (Livak and Schmittgen 2001), where $\Delta \Delta C T=\left(\mathrm{Ct}_{\text {target }}-\mathrm{Ct}_{\text {reference }}\right)_{\text {treatrment }}-\left(\mathrm{Ct}_{\text {target }}-\mathrm{Ct}_{\text {reference }}\right)_{\text {control }}$. qRT-PCR was repeated twice with four independent biological replicates each time.
Yield and fruit quality parameter measurements. For the treatments showing suppressive effect on HLB disease development at 1-year after the initial application, yield of each tree was estimated as the number of boxes of fruit per tree. One box is equivalent to approximately $90 \mathrm{lbs}(40.8 \mathrm{~kg})$ of fruit. Yield data were collected from the trials in Mid-Florida for the 2-year period from 2013 to 2014. A composite of sample from 30 ripe fruit that were randomly chosen from trees within each replicate and represented the mix of symptomatic and asymptomatic fruit present on each tree were used for quality analysis. Fruit were juiced and percentage of juice was calculated according to Gottwald et al. (2012). Juice quality was determined following standard methods described elsewhere (Gottwald et al. 2012). Fruit acidity was expressed as percent citric acid. Total soluble solids was expressed as fruit brix (the measure of sugar content in fruit; i.e., $1 \mathrm{~g}$ of sugar $/ 100 \mathrm{~g}$ of juice is equivalent to $1^{\circ}$ of Brix). Fruit brix acidity ratio was calculated using the data collected.

\section{RESULTS}

Effect of plant defense inducer treatments on HLB disease development. Plant defense inducers were applied for two (for experiments III and IV), three (for experiment II), and four (for experiment I) consecutive growing seasons of three or four applications each. In all four trials, over the experiment duration, for each treatment, the HLB symptoms generally became more severe; i.e., foliar symptoms of blotchy mottle, loss of foliage, dead and dying twigs especially in the upper canopy, and foliar and fruit abscission. These observations were consistent with the disease severity recorded over time, which showed a gradual increase in the severity score for all the treatments over time (Supplementary Figs. S1 to S4). However, some inducers showed various levels of suppressive effect on HLB disease development.

In experiment I, the HLB disease severity (expressed as sAUDPS) in the AA $(60 \mu \mathrm{M}), \mathrm{BABA}(15 \mu \mathrm{M})$, and BABA $(150 \mu \mathrm{M})$ treated groups was reduced by $21.3,28.6$, and $21.4 \%$, respectively, at the end of the experiment compared with the negative control (Fig. 1). The Las bacterial titers in leaves of trees under these three treatments were also significantly lower than the negative control at the end of the experiment (Table 2). The mean values of Las population in the AA $(60 \mu \mathrm{M})$, BABA $(15 \mu \mathrm{M})$, and BABA $(150 \mu \mathrm{M})$ treated groups were $4.91 \times 10^{6}, 4.61 \times 10^{6}$, and $7.18 \times 10^{6}$ cells/g of plant tissue, respectively, while that of the negative control was $2.43 \times 10^{7}$ cells/g of plant tissue (Table 2 ).

In experiment II, the treatments AA $(60 \mu \mathrm{M})$, BABA $(0.2$ to $1.0 \mathrm{mM}), \mathrm{BTH}(1.0 \mathrm{mM})$, INA $(0.1 \mathrm{mM}), 2-\mathrm{DDG}(100 \mu \mathrm{M})$, BABA $(1.0 \mathrm{mM})$ plus BTH $(1.0 \mathrm{mM})$, BTH $(1.0 \mathrm{mM})$ plus AA $(600 \mu \mathrm{M})$, and BTH $(1.0 \mathrm{mM})$ plus 2-DDG $(100 \mu \mathrm{M})$ reduced HLB disease severity by 15 to $25 \%$ at the end of the experiment compared with the negative control (Fig. 1). These treatments also relatively suppressed the growth of Las bacterial populations in citrus leaves compared with the negative control (Table 2). At the end of the experiment, the mean value of Las population of the negative control was $2.68 \times 10^{7}$ cells/g of plant tissue, while those of the treatments were from $3.91 \times 10^{6}$ to $5.84 \times 10^{6}$ cells/g of plant tissue (Table 2).

In experiment III, the treatments BABA $(1.0 \mathrm{mM}), \mathrm{BTH}(1.0 \mathrm{mM})$, INA $(0.5 \mathrm{mM})$, and 2-DDG $(100 \mu \mathrm{M})$ reduced HLB disease severity by 15 to $20 \%$ and suppressed the growth of Las bacterial populations in citrus leaves compared with the negative control (Fig. 2; Table 3). At the end of the experiment, the mean value of Las bacterium population of the treatments ranged from $1.12 \times 10^{7}$ to $1.36 \times 10^{7}$ cells/g of plant tissue, while that of the negative control was $5.15 \times$ $10^{7}$ cells/g of plant tissue (Table 3 ).

In experiment IV, the treatments AA $(600 \mu \mathrm{M})$, BABA $(0.2$ to $1.0 \mathrm{mM})$, BTH $(1.0 \mathrm{mM})$, INA $(0.1$ to $0.5 \mathrm{mM})$, and 2-DDG $(100 \mu \mathrm{M})$ were relatively more effective in suppressing HLB disease development than in experiment III. They reduced the 
disease severity by 20 to $30 \%$, respectively, at the end of the experiment compared with the negative control (Fig. 2). The mean value of Las bacterium population of the negative control was $7.09 \times$ $10^{6}$ cells/g of plant tissue, while those of the treatments were from $1.19 \times 10^{6}$ to $1.83 \times 10^{6}$ cells/g of plant tissue at the end of the experiment (Table 4$)$.

Effect of plant defense inducer treatments on fruit yield and quality. The fruit yield and quality data were collected for the two trials in Mid-Florida. In both trials, the fruit yield generally dropped for each treatment over the experiment duration, however, some treatments showed various levels of positive influence on fruit yield and/or quality (Table 5).

In experiment I, after three seasons of three or four applications each, the treatments AA, BABA, and INA exhibited a higher fruit yield in 2013 compared with the negative control (Table 5). The average weight of fruit per tree of the treatments AA $(60 \mu \mathrm{M})$, BABA (15 to $150 \mu \mathrm{M})$, and INA $(0.1 \mathrm{mM})$ was $45.2,49.8,52.8$, and $43.8 \mathrm{~kg}$ of fruit/tree, respectively, while that of the negative control was $27.8 \mathrm{~kg}$ of fruit/tree. The 2014 yield dropped to approximately $90 \%$ of the 2013 yield for all treatments and the treatments AA $(60 \mu \mathrm{M}), \mathrm{BABA}(15$ to $150 \mu \mathrm{M})$, and INA $(0.1 \mathrm{mM})$ showed a higher fruit yield than the negative control (Table 5). In both years, the treatments AA $(60 \mu \mathrm{M}), \mathrm{BABA}(15$ to $50 \mu \mathrm{M})$, and INA $(0.1 \mathrm{mM})$ exhibited a higher fruit yield than the negative control. There were no significant differences among treatments for fruit quality parameters: percent juice content or juice quality (brix, acid, or brix/acid ratio) in 2013 (Table 5); but in 2014, the treatment BABA $(150 \mu \mathrm{M})$ showed a higher percent juice content and a higher brix/acid ratio than the negative control (Table 5).

In experiment II, there were no apparent differences among treatments in fruit yield ( $\mathrm{kg}$ of fruit/tree) in 2013; but in 2014, the treatments AA, BABA, BTH, 2-DDG, and INA exhibited a higher fruit yield than the negative control (Table 5). The 2014 yield of the treatments AA $(60 \mu \mathrm{M})$, BABA $(0.2$ to $1.0 \mathrm{mM})$, BTH $(1.0 \mathrm{mM})$, 2-DDG $(100 \mu \mathrm{M})$, INA $(0.1 \mathrm{mM})$, BABA $(1.0 \mathrm{mM})$ plus BTH $(1.0 \mathrm{mM})$, BTH $(1.0 \mathrm{mM})$ plus AA $(600 \mu \mathrm{M})$, and BTH $(1.0 \mathrm{mM})$ plus 2-DDG $(100 \mu \mathrm{M})$ was $36.3,37.6,36.5,36.8,35.9,35.6,36.6$, 37.8 , and $36.1 \mathrm{~kg}$ of fruit/tree, respectively, while that of the negative control was $26.9 \mathrm{~kg}$ of fruit/tree, although the 2014 yield dropped to approximately $90 \%$ of the 2013 yield for all treatments (Table 5). Both in 2013 and 2014, the treatments AA $(60 \mu \mathrm{M})$, BABA $(0.2 \mathrm{mM})$, BTH $(1.0 \mathrm{mM})$, INA $(0.1 \mathrm{mM}), 2-\mathrm{DDG}(100 \mu \mathrm{M})$, $\mathrm{BTH}(1.0 \mathrm{mM})$ plus AA $(600 \mu \mathrm{M})$, and BTH $(1.0 \mathrm{mM})$ plus 2-DDG $(100 \mu \mathrm{M})$ showed significant differences in percent fruit juice content, with a higher percent fruit juice compared with the negative control (Table 5). The treatments AA $(60 \mu \mathrm{M})$, BABA $(0.2 \mathrm{mM})$,

TABLE 1. Genes and corresponding primers used in quantitative reverse transcription polymerase chain reaction

\begin{tabular}{|c|c|c|c|}
\hline Gene & Function of protein product & Primer sequence $\left(5^{\prime}-3^{\prime}\right)$ & Reference \\
\hline$P R-2$ & $\beta$-1,3-Glucanase in Citrus sinensis & $\begin{array}{l}\text { Forward: TTCCACTGCCATCGAAACTG } \\
\text { Reverse: GTAATCTTGTTTAAATGAGCCTCTTG }\end{array}$ & Francis et al. (2009) \\
\hline calS1 & Callose synthase 1 & $\begin{array}{l}\text { Forward: TTGCTCCATGGCGGTGCAGA } \\
\text { Reverse: TGGCTGCGGGAGTAAAGCCG }\end{array}$ & Fan et al. (2012) \\
\hline pp2 & Phloem-specific lectin PP2-like protein & $\begin{array}{l}\text { Forward: CGGATTAGACTCGTTGCCAT } \\
\text { Reverse: CGCGATGCAAAAAGTACAGA }\end{array}$ & Fan et al. (2012) \\
\hline$G A P D H-C$ & Glyceraldehyde-3-phosphate dehydrogenase-C & $\begin{array}{l}\text { Forward: GGAAGGTCAAGATCGGAATCAA } \\
\text { Reverse: CGTCCCTCTGCAAGATGACTCT }\end{array}$ & Francis et al. (2009) \\
\hline
\end{tabular}

Experiment I

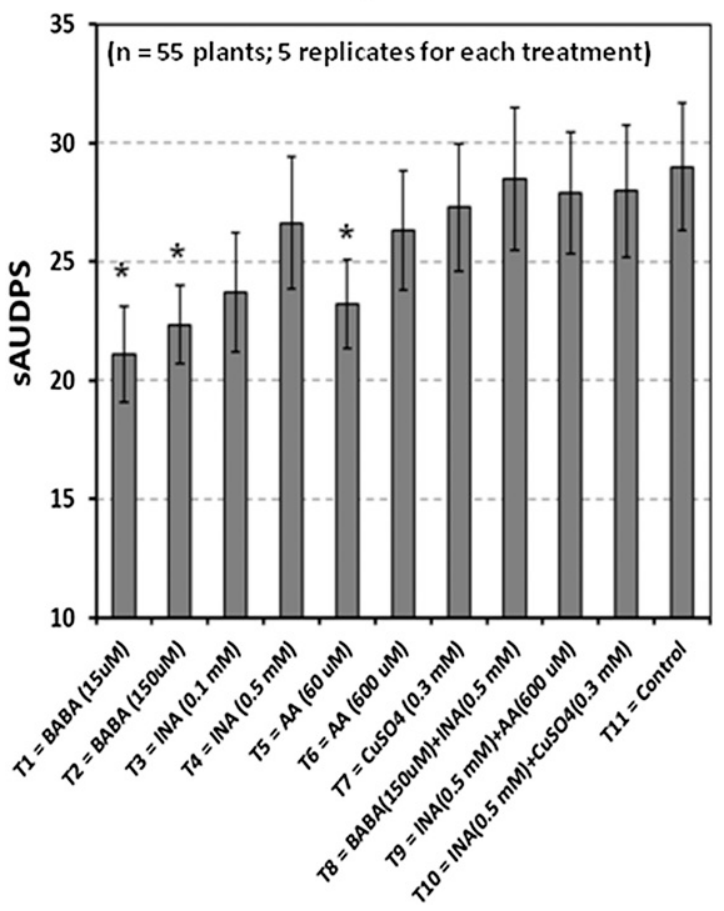

Experiment II

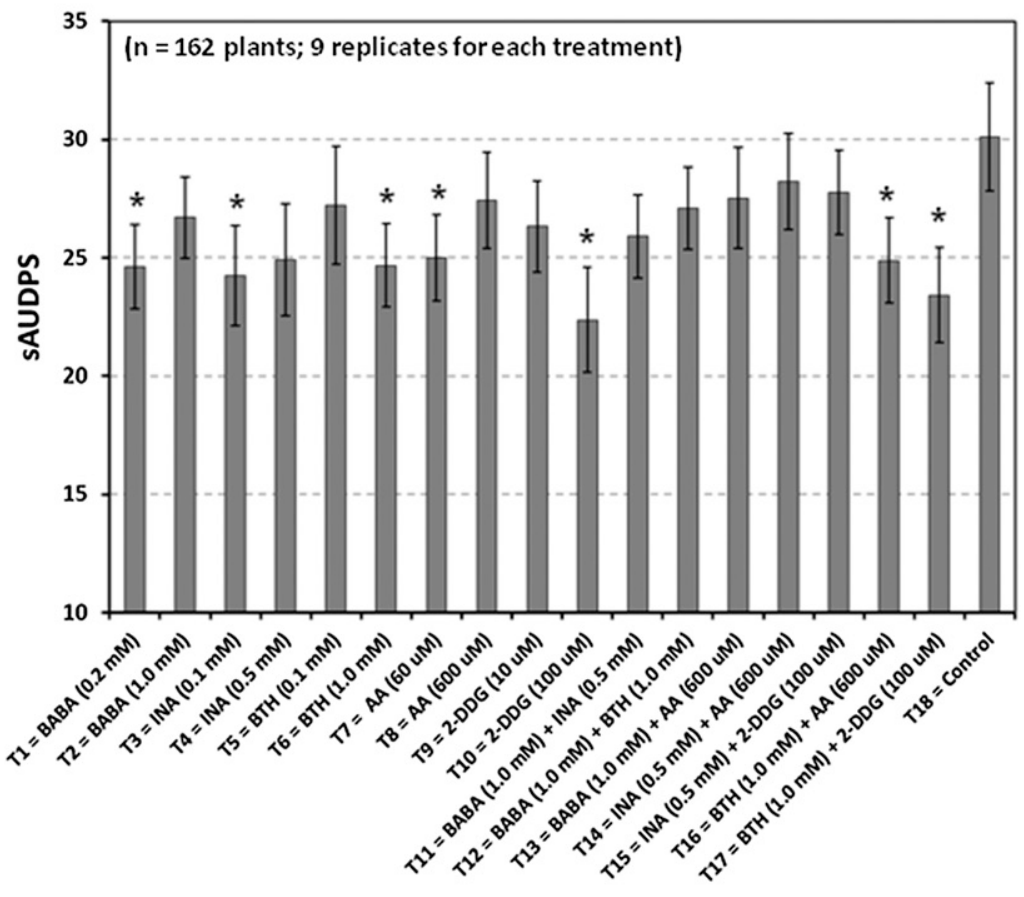

Fig. 1. Disease severity of huanglongbing expressed as the standardized area under the disease progress stairs (sAUDPS) in experiment I and experiment II with Midsweet orange at Mid-Florida over time. Bars represent standard errors of the mean values. Asterisks indicate a significant difference $(P<0.05)$ between the treatment and nontreated control based on Student's $t$ test. 
BTH (1.0 mM), 2-DDG (100 $\mu \mathrm{M})$, and BTH (1.0 mM) plus 2-DDG $(100 \mu \mathrm{M})$ also showed a higher brix/acid ratio than the negative control (Table 5).

Expression of plant defense-related genes. For the treatments showing suppressive effect on HLB disease development after the initial application, we determined the expression pattern of three plant defense-related genes in citrus at four time points: 1, 2, 3, or 4, and 6 days after a single application of treatments by qRT-PCR.

In experiment I, our results showed that the BABA $(150 \mu \mathrm{M})$ induced $P R-2$ expression with an increase in its expression at 2 day after treatment (DAT) and peaking at 3 DAT (Fig. 3A). After treatment with BABA, the levels of gene expression increased to

TABLE 2. 'Candidatus Liberibacter asiaticus' (Las) titers in leaf samples of Midsweet orange under different treatments in experiments I and II at Mid-Florida estimated by quantitative real-time polymerase chain reaction ${ }^{\mathrm{z}}$

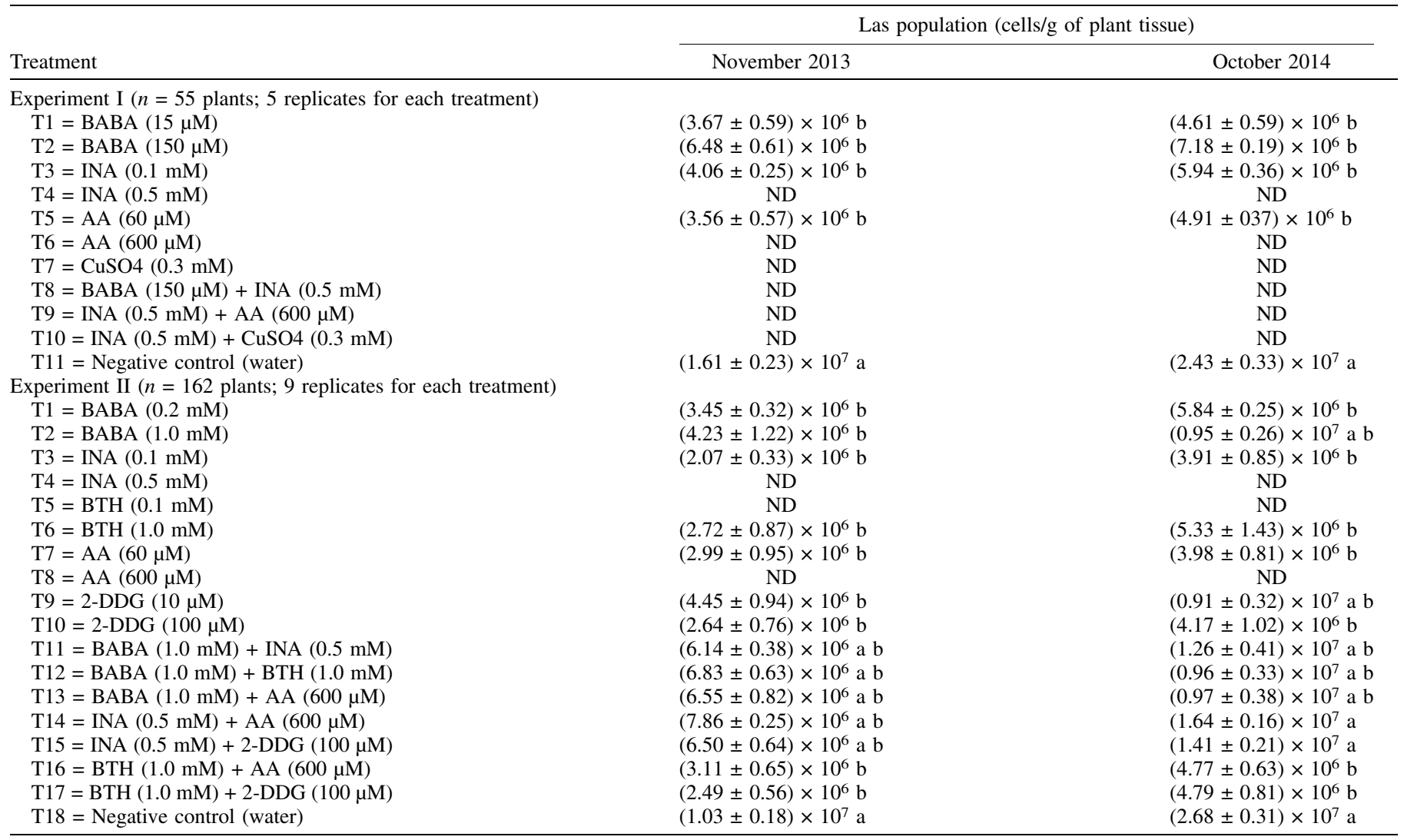

$\mathrm{z}$ Data shown are means and standard errors of three replicates. Values followed by different letters within each column in the same experiment indicate significant difference $(P<0.05$; Student's $t$ test $)$. ND, not determined.

Experiment III

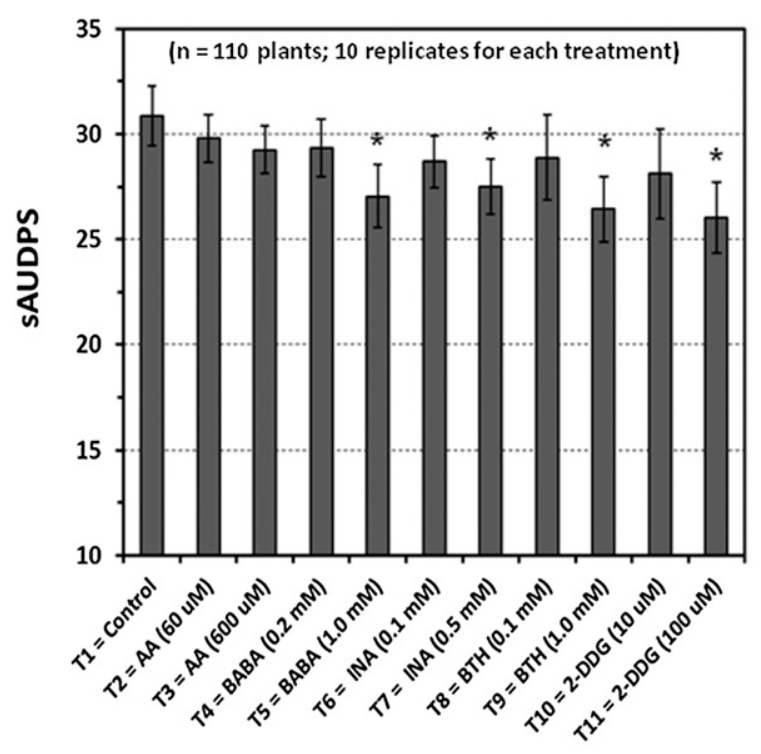

Experiment IV

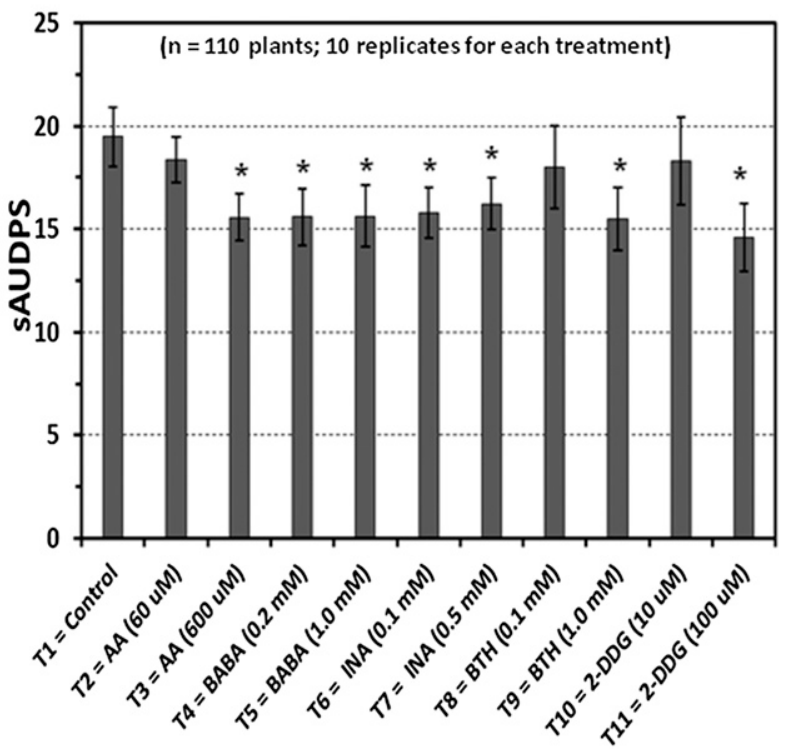

Fig. 2. Disease severity of huanglongbing expressed as the standardized area under the disease progress stairs (sAUDPS) in experiment III with Murcott mandarin and in experiment IV with Valencia sweet orange at Lake Wales, Florida over time. Bars represent standard errors of the mean values. Asterisks indicate a significant difference $(P<0.05)$ between the treatment and nontreated control based on Student's $t$ test. 
3.0-fold at 3 DAT compared with the negative control. However, expression of the $P R-2$ gene had no significant change at 6 days after BABA treatment. BABA treatment had no effect on pp2 (phloem protein-2) or calS1 expression (data not shown). The treatment AA $(60 \mu \mathrm{M})$ or INA $(0.1 \mathrm{mM})$ was not able to induce $P R-2$, calS1, or $p p 2$ gene expression (Fig. 3A; data not shown). In experiment II, $P R-2$ showed a slight induction after BTH $(1.0 \mathrm{mM})$, BTH $(1.0 \mathrm{mM})$ plus AA $(600 \mu \mathrm{M})$, or BTH $(1.0 \mathrm{mM})$ plus 2-DDG $(100 \mu \mathrm{M})$ treatment at 2 DAT, and that level of expression was sustained for two more days before decreasing (Fig. 3B). However, none of the three treatments had effect on $p p 2$ or calS1 expression (data not shown). The treatment 2-DDG $(100 \mu \mathrm{M})$ was not able to induce $P R-2$, pp2, or calS1 (Fig. 3B; data not shown).

\section{DISCUSSION}

It is well documented that a wide range of biotic and abiotic agents are able to induce resistance to pathogen infection in various plants (Durrant and Dong 2004; van Loon et al. 2006; Walters et al. 2013). In this study, we evaluated the effects of various chemical inducer treatments to activate natural plant defense mechanisms against citrus HLB under field conditions. Our findings indicated that the inducing agents tested reduced disease severity by between 15 and $30 \%$ and corresponding effects on fruit yield have also been demonstrated; therefore, this approach may be used and further optimized for control and management of HLB in citrus.

In the present work, we report effectiveness of BABA, BTH, and INA, individually or in combination, suppressing Las population growth and HLB disease progress in infected citrus after field applications for two to four consecutive growing seasons. BTH and
INA, which are functional analogs of SA, have been known to induce resistance against various plant pathogens on a range of crop plants (for review, see Vallad and Goodman 2004; Justyna and Ewa 2013). Particularly, in citrus, soil application of INA induced SAR and presented season-long control of citrus canker caused by Xanthomonas citri subsp. citri (Francis et al. 2009). BTH also activated SAR in sour orange (C. aurantium) (Graham et al. 2012). Similar to these reports, our findings indicated that BTH induced SAR in sweet orange under field conditions, which was confirmed by the observation of increased expression of the SAR marker gene $P R-2$ in response to application of BTH (Fig. 3). Altogether, our observations along with previous reports suggest practical value of using SAR inducing agents to manage pathogens on citrus in the field. Interestingly, SA has been observed to inhibit the growth of Agrobacterium tumefaciens (Yuan et al. 2007; Anand et al. 2008) and Rhizobium meliloti (Martínez-Abarca et al. 1998) at relatively lower concentrations ( 5 to $25 \mu \mathrm{m}$ ) in vitro. Las is believed to be a closely relative of Agrobacterium and Rhizobium, belonging to the family Rhizobiaceae (Duan et al. 2009). Lu et al. (2013) found that Las infection does not lead to significant induction of defenserelated genes or significant accumulation of SA in citrus. It is possible that application of BTH and INA, and the consequent accumulation of SA in citrus may have inhibitory effect on Las even though we could not rule out other possibilities. SA was also found to inhibit the expression of virulence genes (virA/G) in Agrobacterium (Yuan et al. 2007) and induce the expression of two MFStype multicomponent efflux systems in Rhizobium leguminosarum bv. viciae 3841 (Tett et al. 2014). Whether SA and its analogs regulate the expression of virulence genes in Las remains to be characterized.

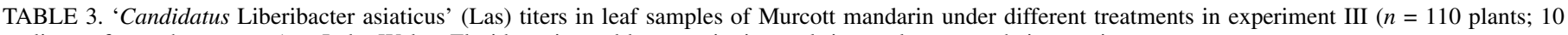
replicates for each treatment) at Lake Wales, Florida estimated by quantitative real-time polymerase chain reaction ${ }^{z}$

\begin{tabular}{|c|c|c|c|c|c|}
\hline \multirow[b]{2}{*}{ Treatment } & \multicolumn{5}{|c|}{ Las population (cells/g of leaf tissue) } \\
\hline & Mar. 2013 & Sep. 2013 & Mar. 2014 & Sep. 2014 & Feb. 2015 \\
\hline $\mathrm{T} 1=$ Water control & $(4.25 \pm 1.02) \times 10^{6} \mathrm{a}$ & $(6.52 \pm 1.05) \times 10^{6} \mathrm{a}$ & $(1.18 \pm 0.32) \times 10^{7} \mathrm{a}$ & $(2.11 \pm 0.36) \times 10^{7} \mathrm{a}$ & $(5.15 \pm 0.26) \times 10^{7} \mathrm{a}$ \\
\hline $\mathrm{T} 2=\mathrm{AA}(60 \mu \mathrm{M})$ & $(2.74 \pm 1.12) \times 10^{6} \mathrm{a}$ & $(3.86 \pm 0.55) \times 10^{6} \mathrm{a}$ & $(0.74 \pm 0.19) \times 10^{7} \mathrm{a}$ & $(1.52 \pm 0.39) \times 10^{7} \mathrm{a}$ & $(2.95 \pm 0.48) \times 10^{7} \mathrm{a}$ \\
\hline $\mathrm{T} 3=\mathrm{AA}(600 \mu \mathrm{M})$ & $(4.12 \pm 0.78) \times 10^{6} \mathrm{a}$ & $(5.23 \pm 0.68) \times 10^{6} \mathrm{a}$ & $(0.91 \pm 0.11) \times 10^{7} \mathrm{a}$ & $(1.84 \pm 0.36) \times 10^{7} \mathrm{a}$ & $(3.12 \pm 0.22) \times 10^{7} \mathrm{a}$ \\
\hline $\mathrm{T} 4=\mathrm{BABA}(0.2 \mathrm{mM})$ & $(3.56 \pm 0.68) \times 10^{6} \mathrm{a}$ & $(4.82 \pm 0.75) \times 10^{6} \mathrm{a}$ & $(0.98 \pm 0.08) \times 10^{7} \mathrm{a}$ & $(1.69 \pm 0.33) \times 10^{7} \mathrm{a}$ & $(3.52 \pm 0.54) \times 10^{7} \mathrm{a}$ \\
\hline $\mathrm{T} 5=\mathrm{BABA}(1.0 \mathrm{mM})$ & $(2.28 \pm 1.03) \times 10^{6} \mathrm{a}$ & $(3.65 \pm 0.45) \times 10^{6} a$ & $(0.76 \pm 0.11) \times 10^{7} \mathrm{a}$ & $(0.84 \pm 0.14) \times 10^{7} b$ & $(1.12 \pm 0.23) \times 10^{7} b$ \\
\hline T6 = INA $(0.1 \mathrm{mM})$ & $(4.02 \pm 0.86) \times 10^{6} \mathrm{a}$ & $(5.23 \pm 0.65) \times 10^{6} \mathrm{a}$ & $(0.98 \pm 0.18) \times 10^{7} \mathrm{a}$ & $(1.57 \pm 0.31) \times 10^{7} \mathrm{a}$ & $(3.45 \pm 0.36) \times 10^{7} \mathrm{a}$ \\
\hline $\mathrm{T} 7=\mathrm{INA}(0.5 \mathrm{mM})$ & $(3.28 \pm 0.77) \times 10^{6} \mathrm{a}$ & $(6.52 \pm 1.05) \times 10^{6} \mathrm{a}$ & $(0.79 \pm 0.19) \times 10^{7} \mathrm{a}$ & $(0.89 \pm 0.12) \times 10^{7} b$ & $(1.36 \pm 0.42) \times 10^{7} b$ \\
\hline $\mathrm{T} 8=\mathrm{BTH}(0.1 \mathrm{mM})$ & $(2.85 \pm 1.04) \times 10^{6} \mathrm{a}$ & $(5.22 \pm 0.83) \times 10^{6} \mathrm{a}$ & $(0.92 \pm 0.07) \times 10^{7} \mathrm{a}$ & $(1.86 \pm 0.28) \times 10^{7} \mathrm{a}$ & $(3.21 \pm 0.41) \times 10^{7} \mathrm{a}$ \\
\hline T9 = ВТН (1.0 mM) & $(3.62 \pm 0.87) \times 10^{6} \mathrm{a}$ & $(4.25 \pm 0.55) \times 10^{6} \mathrm{a}$ & $(0.74 \pm 0.11) \times 10^{7} \mathrm{a}$ & $(0.82 \pm 0.08) \times 10^{7} \mathrm{~b}$ & $(1.26 \pm 0.25) \times 10^{7} b$ \\
\hline $\mathrm{T} 10=2-\mathrm{DDG}(10 \mu \mathrm{M})$ & $(4.53 \pm 1.17) \times 10^{6} \mathrm{a}$ & $(7.12 \pm 1.14) \times 10^{6} \mathrm{a}$ & $(1.13 \pm 0.36) \times 10^{7} \mathrm{a}$ & $(2.06 \pm 0.47) \times 10^{7} \mathrm{a}$ & $(3.74 \pm 0.54) \times 10^{7} \mathrm{a}$ \\
\hline $\mathrm{T} 11=2-\mathrm{DDG}(100 \mu \mathrm{M})$ & $(3.26 \pm 0.72) \times 10^{6} \mathrm{a}$ & $(4.84 \pm 0.67) \times 10^{6} \mathrm{a}$ & $(0.72 \pm 0.12) \times 10^{7} \mathrm{a}$ & $(0.79 \pm 0.07) \times 10^{7} \mathrm{~b}$ & $(1.14 \pm 0.23) \times 10^{7} b$ \\
\hline
\end{tabular}

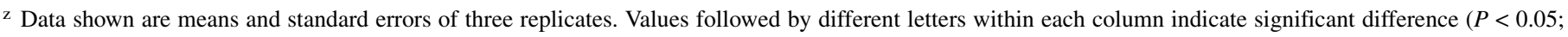
Student's $t$ test).

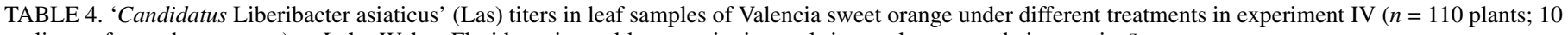
replicates for each treatment) at Lake Wales, Florida estimated by quantitative real-time polymerase chain reaction ${ }^{\mathrm{z}}$

\begin{tabular}{|c|c|c|c|c|c|}
\hline \multirow[b]{2}{*}{ Treatment } & \multicolumn{5}{|c|}{ Las population (cells/g of leaf tissue) } \\
\hline & Mar. 2013 & Sep. 2013 & Mar. 2014 & Sep. 2014 & Feb. 2015 \\
\hline $\mathrm{T} 1=$ Water control & $(4.07 \pm 1.04) \times 10^{5} \mathrm{a}$ & $(0.75 \pm 0.11) \times 10^{6} \mathrm{a}$ & $(1.83 \pm 0.29) \times 10^{6} \mathrm{a}$ & $(3.41 \pm 0.49) \times 10^{6} \mathrm{a}$ & $(7.09 \pm 0.27) \times 10^{6} a$ \\
\hline $\mathrm{T} 2=\mathrm{AA}(60 \mu \mathrm{M})$ & $(3.47 \pm 0.42) \times 10^{5} \mathrm{a}$ & $(0.68 \pm 0.07) \times 10^{6} \mathrm{a}$ & $(1.69 \pm 0.17) \times 10^{6} \mathrm{a}$ & $(2.89 \pm 0.28) \times 10^{6} \mathrm{a}$ & $(6.68 \pm 0.29) \times 10^{6} a$ \\
\hline $\mathrm{T} 3=\mathrm{AA}(600 \mu \mathrm{M})$ & $(3.02 \pm 0.58) \times 10^{5} \mathrm{a}$ & $(0.55 \pm 0.08) \times 10^{6} \mathrm{a}$ & $(0.73 \pm 0.09) \times 10^{6} \mathrm{~b}$ & $(0.93 \pm 0.08) \times 10^{6} b$ & $(1.83 \pm 0.15) \times 10^{6} \mathrm{~b}$ \\
\hline $\mathrm{T} 4=\mathrm{BABA}(0.2 \mathrm{mM})$ & $(5.02 \pm 1.06) \times 10^{5} \mathrm{a}$ & $(0.57 \pm 0.07) \times 10^{6} \mathrm{a}$ & $(0.75 \pm 0.08) \times 10^{6} \mathrm{~b}$ & $(0.97 \pm 0.09) \times 10^{6} b$ & $(1.46 \pm 0.19) \times 10^{6} \mathrm{~b}$ \\
\hline $\mathrm{T} 5=\mathrm{BABA}(1.0 \mathrm{mM})$ & $(2.95 \pm 0.21) \times 10^{5} \mathrm{a}$ & $(0.49 \pm 0.15) \times 10^{6} \mathrm{a}$ & $(0.68 \pm 0.04) \times 10^{6} \mathrm{a}$ & $(0.87 \pm 0.06) \times 10^{6} b$ & $(1.63 \pm 0.34) \times 10^{6} \mathrm{~b}$ \\
\hline T6 = INA $(0.1 \mathrm{mM})$ & $(4.26 \pm 0.57) \times 10^{5} \mathrm{a}$ & $(0.52 \pm 0.13) \times 10^{6} \mathrm{a}$ & $(0.73 \pm 0.04) \times 10^{6} \mathrm{~b}$ & $(0.91 \pm 0.12) \times 10^{6} b$ & $(1.45 \pm 0.11) \times 10^{6} \mathrm{~b}$ \\
\hline $\mathrm{T} 7=\mathrm{INA}(0.5 \mathrm{mM})$ & $(2.96 \pm 0.28) \times 10^{5} \mathrm{a}$ & $(0.51 \pm 0.12) \times 10^{6} \mathrm{a}$ & $(0.76 \pm 0.05) \times 10^{6} \mathrm{~b}$ & $(0.93 \pm 0.11) \times 10^{6} b$ & $(1.48 \pm 0.12) \times 10^{6} \mathrm{~b}$ \\
\hline $\mathrm{T} 8=\mathrm{BTH}(0.1 \mathrm{mM})$ & $(3.51 \pm 1.03) \times 10^{5} \mathrm{a}$ & $(0.68 \pm 0.17) \times 10^{6} \mathrm{a}$ & $(1.96 \pm 0.15) \times 10^{6} \mathrm{a}$ & $(2.63 \pm 0.29) \times 10^{6} \mathrm{a}$ & $(6.53 \pm 0.39) \times 10^{6} a$ \\
\hline $\mathrm{T} 9=\mathrm{BTH}(1.0 \mathrm{mM})$ & $(3.26 \pm 0.29) \times 10^{5} \mathrm{a}$ & $(0.49 \pm 0.14) \times 10^{6} \mathrm{a}$ & $(0.72 \pm 0.06) \times 10^{6} b$ & $(0.89 \pm 0.12) \times 10^{6} b$ & $(1.19 \pm 0.11) \times 10^{6} \mathrm{~b}$ \\
\hline $\mathrm{T} 10=2-\mathrm{DDG}(10 \mu \mathrm{M})$ & $(4.16 \pm 1.11) \times 10^{5} \mathrm{a}$ & $(0.68 \pm 0.06) \times 10^{6} \mathrm{a}$ & $(1.76 \pm 0.07) \times 10^{6} b$ & $(2.83 \pm 0.16) \times 10^{6} \mathrm{a}$ & $(6.64 \pm 0.25) \times 10^{6} a$ \\
\hline $\mathrm{T} 11=2-\mathrm{DDG}(100 \mu \mathrm{M})$ & $(4.45 \pm 0.64) \times 10^{5} \mathrm{a}$ & $(0.55 \pm 0.13) \times 10^{6} \mathrm{a}$ & $(0.86 \pm 0.05) \times 10^{6} \mathrm{~b}$ & $(0.97 \pm 0.14) \times 10^{6} b$ & $(1.48 \pm 0.26) \times 10^{6} \mathrm{~b}$ \\
\hline
\end{tabular}

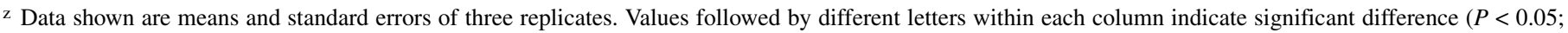
Student's $t$ test). 
BABA is a non-protein amino acid and showed consistent control effect against HLB (Tables 1, 2, 3, and 4; Figs. 1 and 2; Supplementary Figs. S1 to S4). BABA has been known to have control effect against an exceptionally broad spectrum of plant pathogens including Phytophytora infestans on tomatoes (Cohen et al. 1994) and Bremia lactucae on lettuce (Cohen et al. 2010; 2011). BABA can induce plant resistance by priming of SAdependent and SA-independent defense mechanisms (Zimmerli et al. 2000; Ton et al. 2005). The SA-dependent induction of plant resistance by BABA involves activation of SA-inducible defense genes and requires a functional NPR1 protein (Zimmerli et al. 2000); whereas SA-independent BABA induced resistance is related with priming of pathogen-induced callose and requires biosynthesis and perception of abscisic acid (ABA) (Ton et al. 2005; Ton and Mauch-Mani 2004). The control effect of BABA on citrus HLB seems to involve SA-dependent pathway rather than the callose since induction of $P R-2$ gene by BABA was observed (Fig. $3 \mathrm{~A}$ ), whereas induction of calS1 gene, which encodes a callose synthase 1 , by BABA was not observed. BABA-induced resistance has been reported to have long-lasting effect. BABA induced resistance could be detected up to 28 days after soil drench treatment of Arabidopsis with BABA (Luna et al. 2014). In this study, application of BABA led to induction of $P R 2$ gene at 2, and 3 DAT, but not at 6 DAT. This might be due to the presence of salicylic acid (SA) hydroxylase (Duan et al. 2009) encoded by Las which degrades SA (N. Wang, unpublished data). The degradation effect of SA hydroxylase on SA might explain the drop of $P R 2$ gene expression in other treatments, e.g., BTH (Fig. 3B). However, we could not rule out other possibilities responsible for the difference in BABA induced resistance in the previous study (Luna et al. 2014) and this study. For example, it might result from the different application methods with soil drench being used by Luna et al. (2014) whereas foliar spray was used in the current study. BABA not only induces plant defenses against plant pathogens, but also triggers plant defenses against insects. Tiwari et al. (2013) reported that BABA induced plant defenses against Asian citrus psyllid. One caution with application of BABA is that BABA suppresses plant growth when applied in high doses (Cohen 2002). Optimized application of BABA is needed to take advantage of its plant defense inducing against both Las and ACP and avoid potential shortcoming in inhibiting plant growth.

AA also showed positive control effect in suppressing Las population growth and HLB disease progress in infected citrus (Tables 2 and 4; Figs. 1 and 2). AA is an effective antioxidant

TABLE 5. Yield and quality of Midsweet orange fruit harvested from the Mid-Florida citrus grove treated with various plant defense inducers to suppress huanglongbing in 2013 and $2014^{z}$

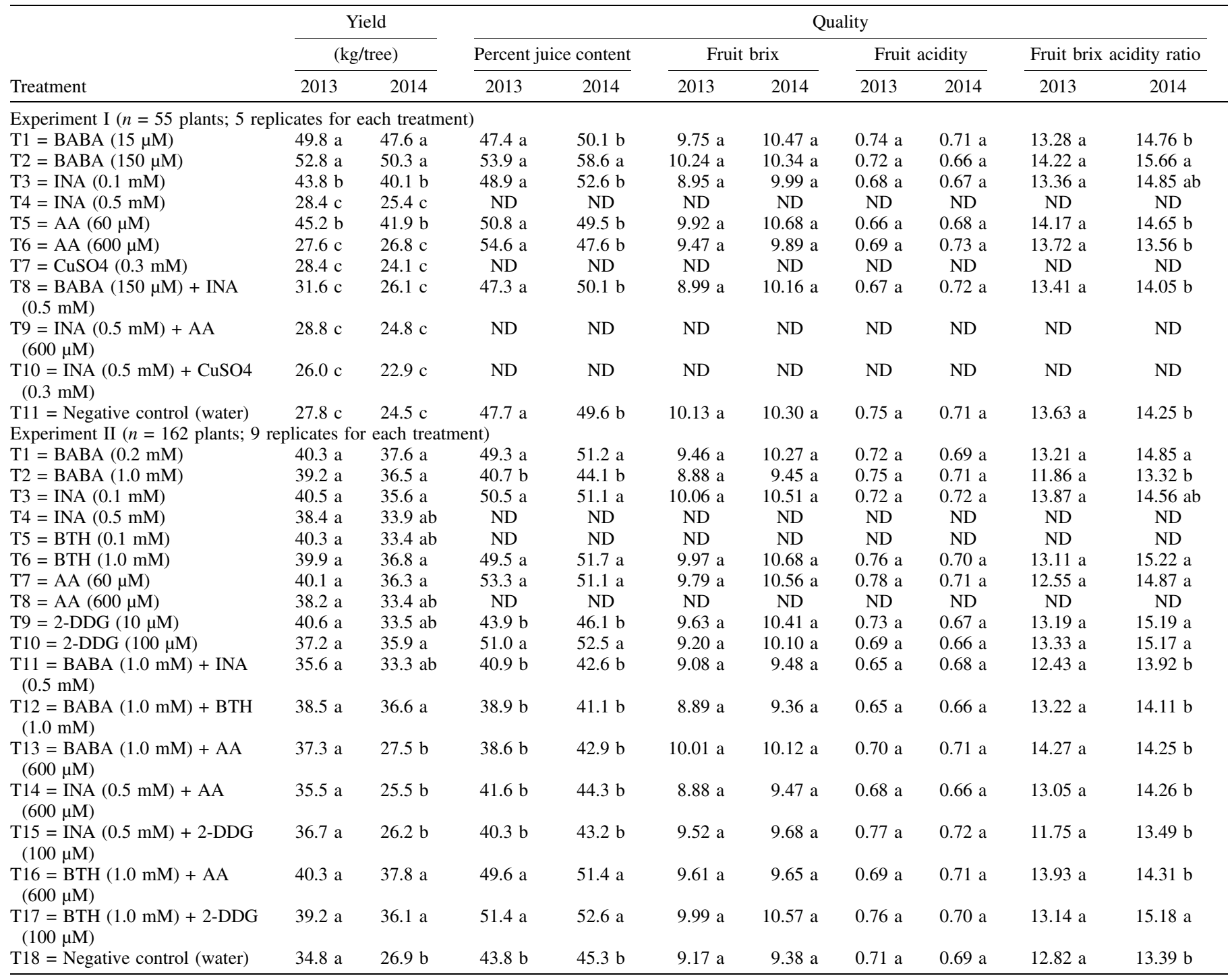

${ }^{\mathrm{z}}$ Each value is the mean of five replicate trees in each treatment (for experiment I) and five randomly selected replicate trees in each treatment (for experiment II). Values followed by different letters within each column in the same experiment indicate significant difference $(P<0.05$; Student's $t$ test). ND, not determined. 
applied in the food, pharmaceutical and cosmetic industries. AA has been demonstrated to be of antimicrobial activity against various microorganisms. For example, AA was suggested to decrease the risk of gastric disease by inhibiting the growth and survival of the associated bacterial pathogen Helicobacter pylori (Tabak et al. 2003). AA also showed antimicrobial and antibiofilm abilities inhibiting the oral microbial growth and biofilm formation of Streptococcus mutans, Staphylococcus aureus, Porphyromonas gingivalis, Candida albicans, and Enterococcus faecalis (SánchezNajera et al. 2013). The applied AA in citrus may probably execute inhibitory activity against Las. In addition, AA also serves as an important cofactor in the biosynthesis of multiple plant hormones, e.g., salicylic acid, jasmonic acid, ethylene, gibberellic acid, and abscisic acid (Barth et al. 2006; Khan et al. 2011). Consequently, AA might alleviate the HLB symptoms by interfering with the biosynthesis of plant hormones and the signaling process.

2-DDG is a non-metabolizable glucose analog and showed positive control effect against HLB (Tables 2, 3, and 4; Figs. 1 and 2). 2-DDG is known as an inhibitor of glucose metabolism that inhibits the glycolytic pathway (Wick et al. 1957). 2-DDG has been found to inhibit the intracellular multiplication of the human bacterial pathogen Legionella pneumophila in $\mathrm{A} / \mathrm{J}$ mouse macrophages (Ogawa et al. 1994) and induce the lysis of growing cultures of
Streptococcus bovis (Russell and Wells 1997). Interestingly, Las encodes a glucose transporter and is capable of importing 2-DDG, however, Las is incapable of metabolizing 2-DDG (Duan et al. 2009). Hence, 2-DDG might have the potential to hamper Las cell growth. 2-DDG also inhibits the growth of several postharvest fungal pathogens Botrytis cinerea, Penicillium expansum, and Rhizopus stolonifer and provides partial control over decay of apple and peach fruit (El-Ghaouth et al. 1995; 1997). In the presence of 2-DDG, the fungi exhibited severe cellular injuries ranging from cell wall disruption to cytoplasm disintegration (El-Ghaouth et al. 1997). In yeast, 2 -DDG causes the erosion of preformed cell wall and prevents the biosynthesis of $\beta-1,3$-glucan (Biely et al. 1971; Moore 1981). Interestingly, $\beta$-1,3-glucan has been identified in the EPS of Agrobacterium spp. and a few Rhizobium strains (Nakanishi et al. 1976; Footrakul et al. 1981; Ghai et al. 1981) which are closely related to Las (Duan et al. 2009). It is possible that 2-DDG could interfere with the $\beta$-1,3-glucan biosynthesis of Las, Agrobacterium and Rhizobium. In addition, Las infection has been known to cause callose deposition, which contributes to the HLB symptom development (Kim et al. 2009). Inhibition of callose formation using callose-inhibitor (Ton and Mauch-Mani 2004) might partially explain the alleviation of HLB symptoms in 2-DDG treated HLBdiseased plants (Figs. 1 and 2).
A

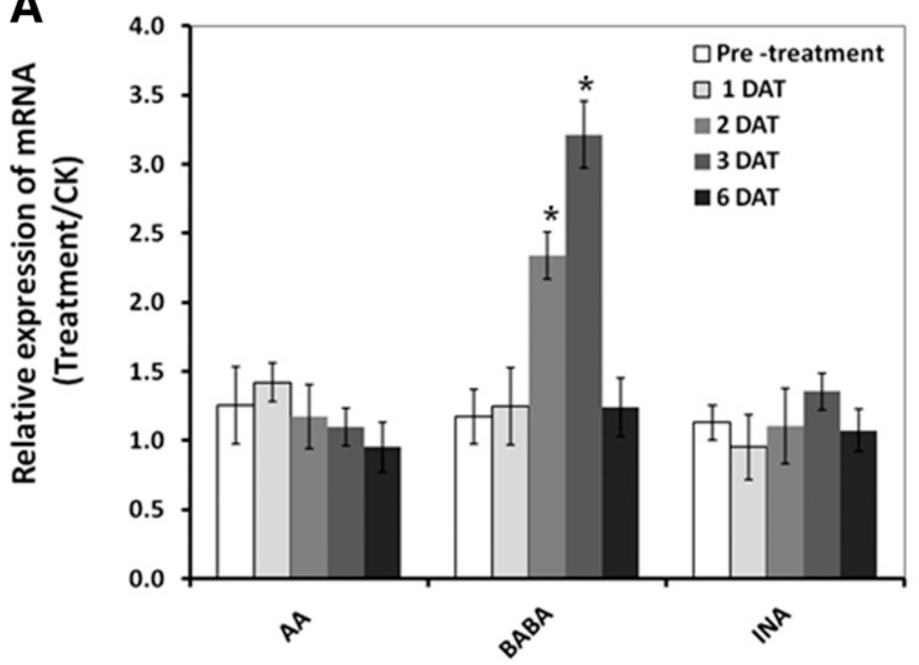

B

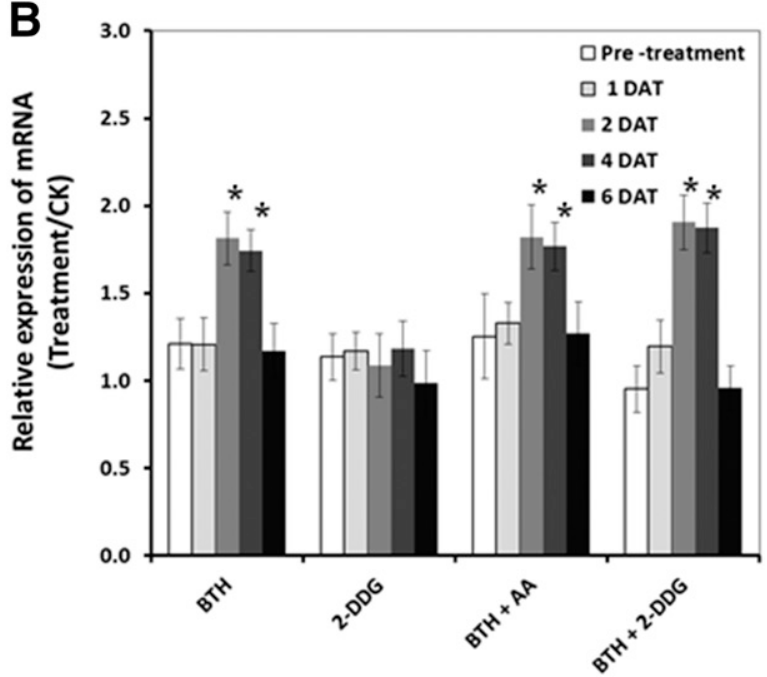

Fig. 3. Relative expression of the $\beta$-1,3-glucanase gene $(P R-2)$ in Midsweet orange leaves after a single application of different plant defense inducer compounds. A, Plants were treated with AA $(60 \mu \mathrm{M})$, BABA $(150 \mu \mathrm{M})$, and INA $(0.1 \mathrm{mM})$, respectively. B, Plants were treated with BTH $(1.0 \mathrm{mM})$, 2-DDG $(100 \mu \mathrm{M})$, BTH $(1.0 \mathrm{mM})$ plus AA $(600 \mu \mathrm{M})$, and BTH $(1.0 \mathrm{mM})$ plus 2-DDG $(100 \mu \mathrm{M})$, respectively. The relative expression change (treatment versus control) was calculated using the $2^{-\Delta \Delta \mathrm{Ct}}$ method. Values represent the mean of three biological replicates and each sample consisted of combined four leaves from one plant (a total of three plants were assayed per treatment). Bars represent standard error. Asterisks indicate a significant difference $(P<0.05)$ between the treatment and nontreated control based on Student's $t$ test. DAT $=$ day after treatment.

TABLE 6. Summary of the best performing treatments in each experiment

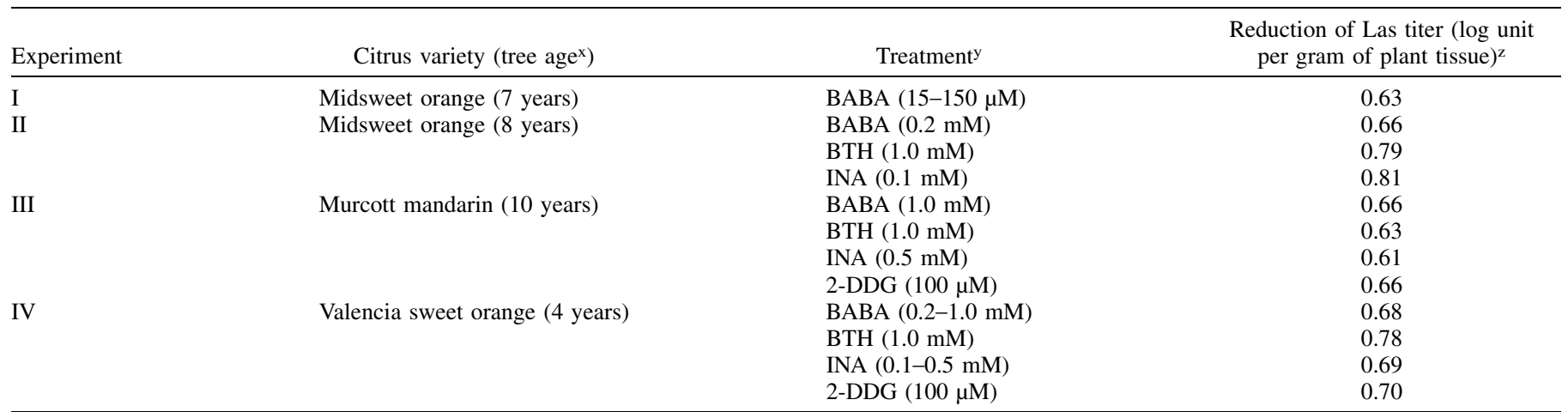

${ }^{x}$ The age at the beginning of the experiment.

y BABA: $\beta$-aminobutyric acid; BTH: 2,1,3-benzothiadiazole; INA: 2,6-dichloroisonicotinic acid; and 2-DDG: 2-deoxy-D-glucose.

$\mathrm{z}$ The reduction in populations of 'Candidatus Liberibacter asiaticus' (Las) compared with control at the end of the experiment. 
We also tested whether combination of different chemicals could increase the control effect against HLB. Surprisingly, as shown in Tables 2 and 5 and Figure 1, combination of BABA $(150 \mu \mathrm{M})$ plus INA $(0.5 \mathrm{mM})$, INA $(0.5 \mathrm{mM})$ plus AA $(600 \mu \mathrm{M})$, BABA $(1.0 \mathrm{mM})$ plus INA $(0.5 \mathrm{mM})$, BABA $(1.0 \mathrm{mM})$ plus BTH $(1.0 \mathrm{mM})$, BABA $(1.0 \mathrm{mM})$ plus AA $(600 \mu \mathrm{M})$, INA $(0.5 \mathrm{mM})$ plus AA $(600 \mu \mathrm{M})$, INA $(0.5 \mathrm{mM})$ plus 2-DDG $(100 \mu \mathrm{M}), \mathrm{BTH}(1.0 \mathrm{mM})$ plus AA $(600 \mu \mathrm{M})$, and BTH $(1.0 \mathrm{mM})$ plus 2-DDG $(100 \mu \mathrm{M})($ Table 2$)$ did not increase the effectiveness of the tested compounds. In some cases, the combined application seems to have a negative effect on the control effect. Previously, it was reported that BABA in combination with other compounds exhibits a synergistic effect. For example, when BABA was applied together with BTH, it greatly enhanced their effectiveness against Peronospora tabacina in tobacco (Cohen 2002). BABA also was synergistic with ASM in the control of Erwinia amylovora in apple and the synergistic effect might be associated with a higher level of SA (Hassan and Buchenauer 2007). In the present study, we did not observe that BABA or BTH provided significantly greater control of HLB disease progress when combined with each other or with other compounds compared with the treatment applied alone. Lack of enhanced effectiveness in combined treatments in this study could have occurred because the concentration of individual compounds tested may not have been sufficiently optimized to cause synergistic effect. Therefore, optimizing the concentration of individual inducing compounds is needed to further evaluate the synergistic effectiveness in induced resistance in citrus after combined treatment with these compounds.

In summary, we observed that the treatments AA, BABA, BTH, 2-DDG, and INA have positive control effect on suppressing Las population in plants and sustain fruit productivity to a certain extent compared with the negative control. The treatments BABA ( 0.2 to $1.0 \mathrm{mM})$ and BTH $(1.0 \mathrm{mM})$ seem to be the most reproducible and effective for application, with a 0.6 to $0.8 \mathrm{log}$ unit reduction in populations of Las per gram of plant tissue after specific chemical treatments (Table 6). Given that the HLB pathogen acquisition by psyllids was positively associated with the bacterial titer in host plants (Coletta-Filho et al. 2014), it is reasonable to speculate that the reduction of Las populations in citrus could also impact the pathogen acquisition and spread by psyllids. Insecticides are currently the most widely used management tool for the psyllid vectors to reduce the transmission of Las (Gottwald et al. 2007), but psyllid populations are developing resistance to insecticides (Tiwari et al. 2011). Our results suggest application of plant defense inducers may provide an additional method for managing HLB. It is worthy to note that induction of plant defense showed relatively more effective to young trees with mild HLB than to old trees with serious HLB. Further research is required to optimize the timing, application methods, e.g., foliar spray, trunk injection, and soil drench, and frequency of defense inducer applications for HLB control and to incorporate induced resistance into disease management programs, with a consideration of economic feasibility.

\section{ACKNOWLEDGMENTS}

This work has been supported by Florida Citrus Research and Development Foundation.

\section{LITERATURE CITED}

Anand, A., Uppalapati, S. R., Ryu, C., Allen, S. N., Kang, L., Tang, Y., and Mysoreet, K. S. 2008. Salicylic acid and systemic acquired resistance play a role in attenuating crown gall disease caused by Agrobacterium tumefaciens. Plant Physiol. 146:703-715.

Aubert, B. 1990. Integrated activities for the control of Huanglongbinggreening and its vector Diaphorina citri Kuwayama in Asia. Pages 133-144 in: Rehabilitation of Citrus Industry in the Asia Pacific Region. Proc. AsiaPac. Int. Conf. Citri Culture. B. Aubert, S. Tontyaporn, and D. Buangsuwon, eds. Chiang Mai, Thailand.
Barth, C., De Tullio, M., and Conklin, P. L. 2006. The role of ascorbic acid in the control of flowering time and the onset of senescence. J. Exp. Bot. 57: 1657-1665.

Beckers, G. J. M., and Conrath, U. 2007. Priming for stress resistance: From the lab to the field. Curr. Opin. Plant Biol. 10:425-431.

Biely, P., Kratky, Z., Kovarik, J., and Bauer, S. 1971. Effect of 2-deoxyglucose on cell wall formation in Saccharomyces cerevisiae and its relation to cell growth inhibition. J. Bacteriol. 107:121-129.

Bové, J. M. 2006. Huanglongbing: A destructive, newly-emerging, century old disease of citrus. J. Plant Pathol. 88:7-37.

Cohen, Y. 2002. $\beta$-Aminobutyric acid-induced resistance against plant pathogens. Plant Dis. 86:448-457.

Cohen, Y., Niderman, T., Mosinger, E., and Fluhr, R. 1994. $\beta$-Aminobutyric acid induces the accumulation of pathogenesis-related proteins in tomato (Lycopersicon esculentum L.) plants and resistance to late blight infection caused by Phytophthora infestans. Plant Physiol. 104:59-66.

Cohen, Y., Rubin, A. E., and Kilfin, G. 2010. Mechanisms of induced resistance in lettuce against Bremia lactucae by DL- $\beta$-aminobutyric acid (BABA). Eur. J. Plant Pathol. 126:553-573.

Cohen, Y., Rubin, A. E., and Vaknin, M. 2011. Post infection application of DL-3-amino-butyric acid (BABA) induces multiple forms of resistance against Bremia lactucae in lettuce. Eur. J. Plant Pathol. 130:13-27.

Coletta-Filho, H. D., Daugherty, M. P., Ferreira, C., and Lopes, J. R. S. 2014. Temporal progression of 'Candidatus Liberibacter asiaticus' infection in citrus and acquisition efficiency by Diaphorina citri. Phytopathology 104: 416-421.

Duan, Y., Zhou, L., Hall, D. G., Li, W., Doddapaneni, H., Lin, H., Liu, L., Vahling, C. M., Gabriel, D. W., and Williams, K. P. 2009. Complete genome sequence of citrus huanglongbing bacterium, 'Candidatus Liberibacter asiaticus' obtained through metagenomics. Mol. Plant-Microbe Interact. 22: 1011-1020.

Durrant, W. E., and Dong, X. 2004. Systemic acquired resistance. Annu. Rev. Phytopathol. 42:185-209.

El Ghaouth, A., Wilson, C., and Wisniewski, M. 1995. Sugar analogs as potential fungicides for postharvest pathogens. Plant Dis. 79:254-258.

El Ghaouth, A., Wilson, C., and Wisniewski, M. 1997. Antifungal activity of 2-deoxy-D-glucose on Botrytis cinerea, Penicillium expansum, and Rhizopus stolonifer: Ultrastructural and cytochemical aspect. Phytopathology 87:772-779.

Fan, J., Chen, C., Yu, Q., Khalaf, A. A., Achor, D. S., Brlansky, R. H., Moore, G. A., Li, Z.-G., and Gmitter, F. G. 2012. Comparative transcriptional and anatomical analyses of tolerant rough lemon and susceptible sweet orange in response to 'Candidatus Liberibacter asiaticus' infection. Mol. PlantMicrobe Interact. 25:1396-1407.

Footrakul, K., Suyanandana, P., Amemura, A., and Harada, T. 1981. Extracellular polysaccharides of Rhizobium from Bangkok MIRCEN collection. J. Ferment. Technol. 59:9-14.

Francis, M. I., Redondo, A., Burns, J. K., and Graham, J. H. 2009. Soil application of imidacloprid and related SAR-inducing compounds produces effective and persistent control of citrus canker. Eur. J. Plant Pathol. 124: 283-292.

Ghai, S. K., Hisamatsu, A., Amemura, A., and Harada, T. 1981. Production and chemical composition of extracellular polysaccharides of Rhizobium. J. Gen. Microbiol. 122:33-40.

Gottwald, T. R. 2010. Current epidemiological understanding of citrus Huanglongbing. Annu. Rev. Phytopathol. 48:119-139.

Gottwald, T. R., da Graça, J. V., and Bassanezi, R. B. 2007. Citrus huanglongbing: The pathogen, its epidemiology, and impact. Online. Plant Health Progress doi:10.1094/PHP-2007-0906-01RV

Gottwald, T. R., Graham, J. H., Irey, M. S., McCollum, T. G., and Woodet, B. W. 2012. Inconsequential effect of nutritional treatments on huanglongbing control, fruit quality, bacterial titer and disease progress. Crop Prot. 36:73-82.

Graham, J. H., Colburn, G. C., Chung, K.-R., and Cuberoet, J. 2012. Protection of citrus roots against infection by Phytophthora spp. by hypovirulent $P$. nicotianae is not related to induction of systemic acquired resistance. Plant Soil 358:39-49.

Halbert, S. E. 2005. The discovery of huanglongbing in Florida. Page 50 in: Proc. 2nd Int. Citrus Canker and Huanglongbing Workshop, Orlando, FL.

Hassan, M. A. E., and Buchenauer, H. 2007. Induction of resistance to fire blight in apple by acibenzolar-S-methyl and DL-3-aminobutyric acid. J. Plant Dis. Prot. 114:151-158.

Hoffman, M. T., Doud, M. S., Williams, L., Zhang, M.-Q., Ding, F., Stover, E., Hall, D., Zhang, S., Jones, L., Gooch, M., Fleites, L., Dixon, W., Gabriel, D., and Duan, Y.-P. 2013. Heat treatment eliminates 'Candidatus Liberibacter asiaticus' from infected citrus trees under controlled conditions. Phytopathology 103:15-22.

Jagoueix, S., Bové, J. M., and Garnier, M. 1994. The phloem-limited bacterium of greening disease of citrus is a member of the alpha subdivision of the Proteobacteria. Int. J. Syst. Bacteriol. 44:379-386. 
Justyna, P.-G., and Ewa, K. 2013. Induction of resistance against pathogens by $\beta$-aminobutyric acid. Acta Physiol. Plant. 35:1735-1748.

Khan, T. A., Mazid, M., and Mohammad, F. 2011. A review of ascorbic acid potentialities against oxidative stress induced in plants. J. Agrobiol. 28:97-111.

Kim, J.-S., Sagaram, U. S., Burns, J. K., Li, J.-L., and Wang, N. 2009. Response of sweet orange (Citrus sinensis) to 'Candidatus Liberibacter asiaticus' infection: Microscopy and microarray analyses. Phytopathology 99: 50-57.

Leonard, M. T., Fagen, J. R., Davis-Richardson, A. G., Davis, M. J., and Triplett, E. W. 2012. Complete genome sequence of Liberibacter crescens BT-1. Stand. Genomic Sci. 7:271-283.

Lin, H., Lou, B., Glynn, J. M., Doddapaneni, H., Civerolo, E. L., Chen, C., Duan, Y., Zhou, L., and Vahling, C. M. 2011. The complete genome sequence of 'Candidatus Liberibacter solanacearum', the bacterium associated with potato zebra chip disease. PLoS One 6:e19135.

Livak, K. J., and Schmittgen, T. D. 2001. Analysis of relative gene expression data using real-time quantitative PCR and the $2^{-\Delta \Delta C T}$ method. Methods 25: 402-408.

Lu, H., Zhang, C., Albrecht, U., Wang, G., and Bowman, K. D. 2013. Overexpression of a citrus NDR1 ortholog increases disease resistance in Arabidopsis. Front. Plant Sci. 4:157.

Luna, E., López, A., Kooiman, J., and Ton, J. 2014. Role of NPR1 and KYP in long-lasting induced resistance by $\beta$-aminobutyric acid. Front. Plant Sci. 5: 184.

Martínez-Abarca, F., Herrera-Cervera, J. A., Bueno, P., Sanjuan, J., Bisseling, T., and Olivares, J. 1998. Involvement of salicylic acid in the establishment of the Rhizobium meliloti-alfalfa symbiosis. Mol. Plant-Microbe Interact. 11:153-155.

Moore, D. 1981. Effect of hexose analogs on fungi: Mechanisms of inhibition and resistance. New Phytol. 87:487-515.

Nakanishi, I., Kimura, K., Suzuki, T., Ishikawa, M., Banno, I., Sakane, T., and Harada, T. 1976. Demonstration of curdlan-type polysaccharide and some other $\beta$-1,3-glucan in microorganisms with aniline blue. J. Gen. Appl. Microbiol. 22:1-11.

Ogawa, M., Yoshida, S.-I., and Mizuguchi, Y. 1994. 2-Deoxy-D-glucose inhibits intracellular multiplication and promotes intracellular killing of Legionella pneumophila in A/J mouse macrophages. Infect. Immun. 62:266-270.

Pagliai, F. A., Gardner, C. L., Bojilova, L., Sarnegrim, A., Tamayo, C., Potts, A. H., Teplitski, M., Folimonova, S. Y., Gonzalez, C. F., and Lorca, G. L. 2014. The transcriptional activator LdtR from 'Candidatus Liberibacter asiaticus' mediates osmotic stress tolerance. PLoS Pathog 10:e1004101.

Pelz-Stelinski, K. S., Brlansky, R. H., Ebert, T. A., and Rogers, M. E. 2010. Transmission parameters for Candidatus Liberibacter asiaticus by Asian citrus psyllid (Hemiptera: Psyllidae). J. Econ. Entomol. 103:1531-1541.

Russell, J. B., and Wells, J. E. 1997. The ability of 2-deoxyglucose to promote the lysis of Streptococcus bovis JB1 via a mechanism involving cell wall stability. Curr. Microbiol. 35:299-304.

Sánchez-Najera, R., Isela, Nakagoshi-Cepeda, S., Martínez-Sanmiguel, J. J., Hernandez-Delgadillo, R., and Cabral-Romero, C. 2013. Ascorbic acid on oral microbial growth and biofilm formation. Pharma Innov. 2:103-109.

Simko, I., and Piepho, H.-P. 2012. The area under the disease progress stairs: Calculation, advantage, and application. Phytopathology 102:381-389.

Stansly, P. A., Arevalo, H. A., Qureshi, J. A., Jones, M. M., Hendricks, K., Roberts, P. D., and Rokaet, F. M. 2014. Vector control and foliar nutrition to maintain economic sustainability of bearing citrus in Florida groves affected by huanglongbing. Pest Manag. Sci. 70:415-426.

Sutton, B., Duan, Y. P., Halbert, S., Sun, X. A., Schubert, T., and Dixon, W. 2005. Detection and identification of citrus Huanglongbing (greening) in Florida. Page 59 in: Proc. Second Int. Citrus Canker Huanglongbing Res. Workshop, Orlando, FL.

Tabak, M., Armon, R., Rosenblat, G., Stermer, E., and Neemanet, I. 2003. Diverse effects of ascorbic acid and palmitoyl ascorbate on Helicobacter pylori survival and growth. FEMS Microbiol. Lett. 224:247-253.

Teixeira, D. A., Eveillard, S., Martins, E. C., Jesus, W. C., Jr., Yamamoto, P. T., Lopes, S. A., Bassanezi, R. B., Ayres, A. J., Saillard, C., and Bové, J. M. 2005. Citrus huanglongbing in São Paulo State, Brazil: PCR detection of the 'Candidatus Liberibacter' species associated with the disease. Mol. Cell. Probes 19:173-179.
Tett, A. J., Karunakaran, R., and Poole, P. S. 2014. Characterisation of SalRAB a salicylic acid inducible positively regulated efflux system of Rhizobium leguminosarum bv. viciae 3841. PLoS One 9:e103647.

Tiwari, S., Mann, R. S., Rogers, M. E., and Stelinski, L. L. 2011. Insecticide resistance in field populations of Asian citrus psyllid in Florida. Pest Manag. Sci. 67:1258-1268

Tiwari, S., Meyer, W. L., and Stelinski, L. L. 2013. Induced resistance against the Asian citrus psyllid, Diaphorina citri, by $\beta$-aminobutyric acid in citrus. Bull. Entomol. Res. 103:592-600.

Ton, J., Jakab, G., Toquin, V., Flors, V., Iavicoli, A., Maeder, M. N., Metraux, J. P., and Mauch-Mani, B. 2005. Dissecting the $\beta$-aminobutyric acid induced priming phenomenon in Arabidopsis. Plant Cell 17:987-999.

Ton, J., and Mauch-Mani, B. 2004. $\beta$-Amino-butyric acid-induced resistance against necrotrophic pathogens is based on ABA-dependent priming for callose. Plant J. 38:119-130.

Trivedi, P., Sagaram, U. S., Kim, J. S., Brlansky, R. H., Rogers, M., Stelinski, L. L., Oswalt, C., Kim, J. S., and Wang, N. 2009. Quantification of viable Candidatus Liberibacter asiaticus in hosts using quantitative PCR with the aid of ethidium monoazide (EMA). Eur. J. Plant Pathol. 124:553-563.

Vallad, G. E., and Goodman, R. M. 2004. Systemic acquired resistance and induced systemic resistance in conventional agriculture. Crop Sci. 44: 1920-1934.

van Loon, L. C., Rep, M., and Pieterse, C. M. J. 2006. Significance of inducible defense-related proteins in infected plants. Annu. Rev. Phytopathol. 44:135-162.

Walters, D., Walsh, D., Newton, A., and Lyon, G. 2005. Induced resistance for plant disease control: Maximizing the efficacy of resistance elicitors. Phytopathology 95:1368-1373.

Walters, D. R., Ratsep, J., and Havis, N. D. 2013. Controlling crop diseases using induced resistance: Challenges for the future. J. Exp. Bot. 64: 1263-1280.

Wang, N., and Trivedi, P. 2013. Citrus Huanglongbing: An old problem with an unprecedented challenge. Phytopathology 103:652-665.

Wang, Z., Yin, Y., Hu, H., Yuan, Q., Peng, G., and Xia, Y. 2006. Development and application of molecular-based diagnosis for 'Candidatus Liberibacter asiaticus', the causal pathogen of citrus huanglongbing. Plant Pathol. 55: 630-638.

Weller, D. M., Mavrodi, D. V., van Pelt, J. A., Pieterse, C. M. J., van Loon, L. C., and Bakker, P. A. H. M. 2012. Induced systemic resistance in Arabidopsis thaliana against Pseudomonas syringae pv. tomato by 2,4diacetylphloroglucinol producing Pseudomonas fluorescens. Phytopathology 102:403-412.

Wick, A. N., Drury, D. R., Nakada, H. I., and Wolfe, J. B. 1957. Localization of the primary metabolic block produced by 2-deoxyglucose. J. Biol. Chem. 224:963-969.

Wulff, N. A., Zhang, S., Setubal, J. C., Almeida, N. F., Martins, E. C., Harakava, R., Kumar, D., Rangel, L. T., Foissac, X., Bové, J. M., and Gabriel, D. W. 2014. The complete genome sequence of 'Candidatus Liberibacter americanus', associated with citrus huanglongbing. Mol. PlantMicrobe Interact. 27:163-176.

Xu, M., Liang, M., Chen, J., Xia, Y., Zheng, Z., Zhu, Q., and Deng, X. 2013. Preliminary research on soil conditioner mediated citrus Huanglongbing mitigation in the field in Guangdong, China. Eur. J. Plant Pathol. 137: 283-293.

Yuan, Z.-C., Edlind, M. P., Liu, P., Saenkham, P., Banta, L. M., Wise, A. A., Ronzone, E., Binns, A. N., Kerr, K., and Nester, E. W. 2007. The plant signal salicylic acid shuts down expression of the vir regulon and activates quorum-quenching genes in Agrobacterium. Proc. Natl. Acad. Sci. USA 104:11790-11795.

Zamioudis, C., and Pieterse, C. M. J. 2012. Modulation of host immunity by beneficial microbes. Mol. Plant-Microbe Interact. 25:139-150.

Zhang, M. Q., Powell, C. A., Zhou, L. J., He, Z. L., Stover, E., and Duan, Y. P. 2011. Chemical compounds effective against the citrus Huanglongbing bacterium 'Candidatus Liberibacter asiaticus' in planta. Phytopathology 101:1097-1103.

Zimmerli, L., Jakab, C., Metraux, J. P., and Mauch-Mani, B. 2000. Potentiation of pathogen-specific defense mechanisms in Arabidopsis by $\beta$-aminobutyric acid. Proc. Natl. Acad. Sci. USA 97:12920-12925. 